\title{
Efficacy of sumac spice incorporation in Egyptian kofta against Staphylococcus aureus and Enterobacteriaceae
}

\author{
${ }^{1,{ }^{*}}$ Ahmed, A.M., ${ }^{2}$ Mohamed, S.J., ${ }^{3}$ Ismail, T.H. and ${ }^{2}$ Shaheen, H.M. \\ ${ }^{1}$ Department of Food Hygiene, Faculty of Veterinary Medicine, Arish University, Egypt \\ ${ }^{2}$ Department of Food Hygiene, Faculty of Veterinary Medicine, Suez Canal University, Ismailia, Egypt \\ ${ }^{3}$ Department of Food Hygiene, Animal Health Research Institute, Ismailia Branch, Egypt
}

\section{Article history:}

Received: 23 June 2020

Received in revised form: 2

July 2020

Accepted: 16 July 2020

Available Online: 16

September 2020

\section{Keywords:}

Kofta,

Sumac,

Staphylococcus aureus,

Enterobacteriaceae,

Shelf life

\section{DOI:}

https://doi.org/10.26656/fr.2017.4(6).291

\begin{abstract}
Egyptian kofta is considered one of the processed meat products with high nutritional value with an economic price, suiting a wide range of consumers. So, it requires protection from microbial contamination during their preparation, storage, and distribution. Sumac (Rhus coriaria) spice extract can be considered as herbal antimicrobial shown to have their activities against many foodborne pathogens. The antibacterial activities of different concentrations of sumac spice extract $(1 \%, 2.5 \%$ and 5\%) were tested in vitro against Staphylococcus aureus and Enterobacteriaceae using the agar disc diffusion method. The average value of total $S$. aureus count $(\mathrm{CFU} / \mathrm{g})$ in untreated samples (control) was $1.1 \times 10^{4} \pm 7.6 \times 10^{2} \mathrm{CFU} / \mathrm{g}$ at the 6th day during chilling storage which significantly $(\mathrm{p}<0.05)$ decrease at the 9 th day of storage to $7 \times 10^{4} \pm 3.4 \times 10^{3}$, $9 \times 10^{3} \pm 1.1 \times 10^{2}$ and $8 \times 10^{3} \pm 2.9 \times 10^{2} \mathrm{CFU} / \mathrm{g}$ in treated samples with $1 \%, 2.5 \%$ and $5 \%$ sumac spice extract respectively. The average value of total Enterobacteriaceae count in the 6th day was $1 \times 10^{4} \pm 3.5 \times 10^{2} \mathrm{CFU} / \mathrm{g}$ in the untreated kofta samples which significantly $(\mathrm{p}<0.05)$ decrease in the 9 th day of storage to $1.1 \times 10^{4} \pm 1 \times 10^{3}, 9 \times 10^{3} \pm 1.7 \times 10^{2}$ and $8.1 \times 10^{3} \pm 77.7 \mathrm{CFU} / \mathrm{g}$ in treated samples with $1 \%, 2.5 \%$ and $5 \%$ sumac spice extract respectively. Our findings suggested the possibility of using the fruit of Sumac as a novel source of natural antimicrobial for the food industries.
\end{abstract}

\section{Introduction}

Meat and meat products are very popular food in Egypt as well as throughout the world. No wonder since they are delicious as considered as good and cheap sources of protein characterized by good flavor and easily digested. The increase of human population and the great progress of various aspects of life make the consumer to use meat products in different forms for their ease preparation such as kofta (Saad et al., 2018).

Kofta is a family of meatball which consists of minced or ground meat, usually beef, mixed with spices or onion. It can be exposed to several ways of contamination through improper preparation, bad handling of foods and improper storage which constitute the most direct and harmful source of microbiological contamination (Hassan et al., 2015).

A major problem in food hygiene is the fecal contamination of meat product with Enterobacteriaceae such as Salmonella spp., Escherichia coli, Proteus, and
Klebsiella species. The bacterial contamination and hygienic measures during meat production can be measured using the aerobic plate count, total Enterobacteriaceae and total coliforms counts (McEvovy et al., 2004).

Staphylococcus aureus plays a great role in bacterial contamination of cooked meat, Staphylococcus can carry on human hands, nasal passage or throats, so workers play as major role of $S$. aureus contamination during preparation, processing, or even through post cooking contamination by touching cooked meat that are usually eaten without further cooking or heating. Most foodborne illnesses of $S$. aureus outbreaks are a result of production of heat stable toxins in the meat which may lead to severe food poisoning outbreaks (United Stated Department of Agriculture, Food Safety and Inspection Service, 2003)

Therefore, new preservation techniques needed to improve the quality and safety of meat products, with maintaining their good nutritional and organoleptic 
properties due to the growing demand of consumers for safe and natural products (Burt, 2004).Thousand years ago, many spices had been used as preservatives due to their antimicrobial and antioxidant effect beside being flavoring and coloring agents (Srinivasan, 2005).

Sumac (Rhus coriaria and related to familyAnacardiaceae) is a very popular spice in countries of the Middle East, where it is widely used in meat dishes. Sumac is used in most Arab countries, the term sumac is derived from the Arabic root, summaq, meaning red, referring to the colour of sumac fruit (Figure 1). Sumac belongs to the genus Rhus, found in subtropical and temperate regions throughout the world. Sumac plants are large shrubs or small trees, reaching a height of 3 $10 \mathrm{~m}$, with pinnately compound leaves. They bear greenish white flowers in dense panicles and red drupaceous fruits (also called sumac bobs), from which the spice (Figure 2) is derived (Ravindran et al., 2012).

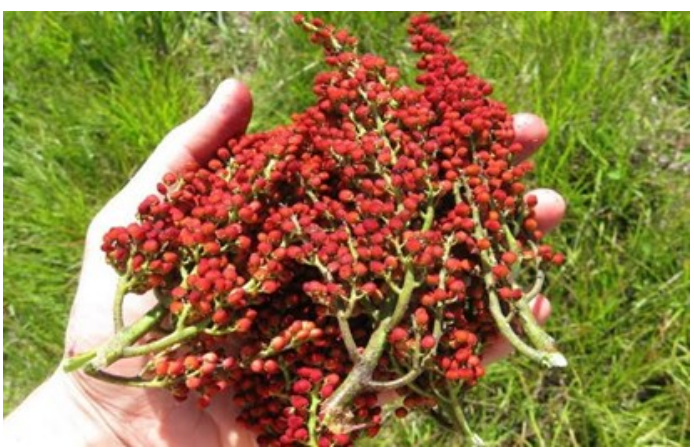

Figure 1. Fresh sumac (Rhuscoriaria) fruit in the autumn season

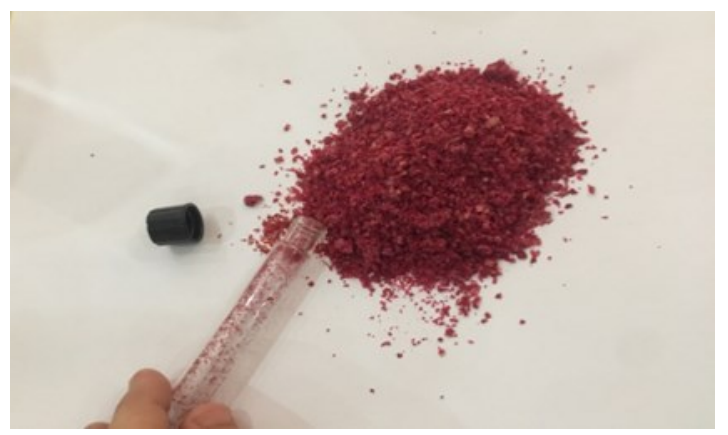

Figure 2. Illustrate sumac spice collected from Ismailia markets

Phytochemicals in Rhuscoriaria are being used as antibacterial, antidiarrhoea, antidysenteric, antihepatoxic and antiseptic due to their contents of ellagic acid, gallic acid, isoquercitrin, myricitrin, myricetin, quercetin, quercitrin and tannic acid (Al-Mizraqch et al., 2010). Therefore, this study was carried out to investigate the antimicrobial effect of sumac spice extract and to evaluate the effect of different concentration of the prepared extracts against, $S$. aureus and Enterobacteriaceae counts in kofta for enhancing bacteriological quality.

\section{Materials and methods}

\subsection{Collection of plant material}

The ripened (reddish-brown), native sumac spice (Rhuscoriaria) bought from local markets in Ismailia Governorate.

\subsection{Preparation of plant extract}

The sumac ethanol extract was prepared as described by Abd El-Mawla (1996), with some modification. The extracted prepared in Pharmacology Department in Suez Canal University by maceration technique as the following: $250 \mathrm{~g}$ of sumac spice macerated in $750 \mathrm{~mL}$ of absolute ethanol $99.9 \%$ then allowed to complete exhaustion. The final extract (bright reddish mixture) filtered and the filtrate was concentrated in rotatory evaporator (R-100 Buchi- Switzerland) under reduced pressure until complete evaporation. The yield after complete evaporation of ethanol was $53 \mathrm{~g}$ of the sumacdried extract for each $250 \mathrm{~g}$ of spice. The sumac dried extract emulsified by sterile propylene glycol to give final concentration of $1 \%, 2.5 \%$ and $5 \%$; these concentrations were according to Nasar et al. (2004). The extract kept in sealed containers and refrigerated at $3 \pm 1^{\circ} \mathrm{C}$ until used in bacteriological evaluation. Propylene glycol commonly used as an excipient in a variety of drugs and it authorized in food products and cosmetics (European Medicines Agency, 2013) and it gave antibacterial activity at $100 \%$ concentration (Nalawade et al., 2015).

\subsection{Preparation of Egyptian kofta}

Fresh beef meat sample purchased from local market at Ismailia Governorate (Egypt) on the day of preparation. It cut and minced with grinder through a 4 $\mathrm{mm}$ plate diameter then $17 \mathrm{~g}$ of common salt added for each one $\mathrm{kg}$ of meat. Then it was divided into four groups, first group was a control group with $0 \%$ sumac spice extract, $2^{\text {nd }}$ group was mixed with $1 \%$ sumac spice extract while $3^{\text {rd }}$ and $4^{\text {th }}$ groups were mixed with $2.5 \%$, and 5\% sumac spice extract respectively. Then each group divided to 30 samples (each about $50 \mathrm{~g}$ ). Each sample formed into meatballs (kofta), then wrapped with saran wrap, and placed in a chiller at $3 \pm 1^{\circ} \mathrm{C}$ for zero, third, sixth, ninth, eleventh and fifteenth days. Five samples (from control and each concentration) were removed for bacteriological evaluation periodically.

\subsection{Determination of antimicrobial activity of the prepared extract}

The antimicrobial activity of the prepared extracts was tested in vitro against $S$. aureus and Enterobacteriaceae using the agar disc diffusion method according to National Committee for Clinical Laboratory 
Standards (1993).

\subsection{Bacteriological evaluation}

Samples homogenate and serial decimal dilutions were prepared following the recommendation of Downes and Ito (2001).The serial dilutions of each sample examined for evaluation the effect of the added extracts on $S$. aureus count (Downes and Ito 2001) and total Enterobacteriaceae count (ISO, 2004).

\subsection{Statistical analysis}

All values presented as mean \pm standard error. Data analysis was performed by using SPSS statistical software program (SPSS, 2007). Data analyzed for the significant differences between fresh and cooked offal. Data subjected to one-way analysis of variance (ANOVA). Any significant differences $(p<0.05)$ were analyzed by the multiple comparison procedure of LSD (least significant differences), using a level of significance of alpha $=0.05$.

\section{Results and discussion}

The emergence of natural food preservatives against the currently used chemical agents is on the raise and requires worldwide consideration. Food investigators on the use of plants as antimicrobials will not only authenticate their use in preservatives of meat products but will provide future promises in the discovery of new drugs with antimicrobial potential.

\subsection{Determination of antimicrobial activity of the prepared extract}

There is an interest in discovering new natural antimicrobials such as spices, herbs and their extracts. The sumac extract displayed a variable degree of antimicrobial activity on different bacteria (Nasar et al., 2004).

The result obtained in Table 1 revealed that theinhibition zone (mm) of sumac spice extract against $S$. aureus and Enterobacteriaceae. For S. aureus it was 13, 16 and $17 \mathrm{~mm}$ at concentration level 1\%, 2.5\% and 5\% while the control positive Norfloxacin $10_{\mathrm{mcg}}$ gave $24 \mathrm{~mm}$. These results was nearly similar to Nimri et al. (1999), Bonjar (2004), Nasar et al. (2004), Akrayi and Abdullrahman (2013), Yadolahi et al. (2017) and Khalkhali and Noveir (2018) while high recordes were reported by Abu-Shanab et al. (2005), Ali et al. (2013), Gabr et al. (2014) and Mahdi et al. (2016) and lower results recorded by Ertürk (2010) and Qadir et al.(2013). While for Enterobacteriaceae the inhibatory zone (mm) of sumac extract against at concentration level 1\%, 2.5\% and $5 \%$ were 8,11 and $15 \mathrm{~mm}$, respectively while the control positive Norfloxacin $10_{\mathrm{mcg}}$ gave $28 \mathrm{~mm}$. These results were nearly similar to Nimri et al. (1999), Nasar et al. (2004), Moshtaghi et al. (2013), Aliakbarlu et al. (2014) and Khalkhali and Noveir (2018),while high recordes were reported by Abu-Shanab et al. (2005), Ali et al. (2013), Gabr et al. (2014) and Mahdi et al. (2016) meanwhile lower results recorded by Ertürk (2010) and Qadir et al. (2013).

Table 1. Sensitivity test of sumac spice extract against $S$. aureus and Enterobacteriaceae

\begin{tabular}{cccc}
\hline Treatment & $\begin{array}{c}\text { Conc. } \\
\text { Level (\%) }\end{array}$ & $\begin{array}{c}\text { Inhibition zone } \\
\text { for S. aureus } \\
(\mathrm{mm})\end{array}$ & $\begin{array}{c}\text { Inhibition zone for } \\
\text { Enterobacteriaceae } \\
\text { (mm) }\end{array}$ \\
\hline Sumac spice & $1 \%$ & 13 & 8 \\
extract & $2.50 \%$ & 16 & 11 \\
Norfloxacin & $5 \%$ & 17 & 15 \\
\hline
\end{tabular}

Norfloxacin considered as control positive

These results showed that there is an inhibitory effect of sumac against $S$. aureus and Enterobacteriaceae, which increase with concentration. Sumac extract gave higher inhibition zone against $S$. aureus comparing to Enterobacteriaceae that agreed with Saxena et al. (1994), Fazeli et al. (2007), Raodah et al. (2014) and Abou-Reidah et al. (2014) whose results cleared that Gram-positive bacteria were more sensitive than Gram-negative bacteria when treated with sumac. This may be due to the differences in cell wall structures between Gram-positive and Gram-negative bacteria. The presence of lipopolysaccharides in the outer membrane of Gram-negative bacteria makes their membrane act as a barrier against many natural substances.

\subsection{Bacteriological evaluation}

Plants are able to produce different compounds that used to protect themselves against different types of pathogens. These compounds like phenolic acid that has antimicrobials action as it interact with the proteins (Cowan, 1999).

\subsubsection{Effect of sumac spice extract on $S$. aureus count}

Results given in Table 2 showed the effect of sumac spice extract on total $S$. aureus count $(\mathrm{CFU} / \mathrm{g})$ in the treated kofta samples. In zero-day, the mean value \pm standard error in group 1, group 2, group 3 and group 4 was $5.3 \times 10^{3} \pm 5.6 \times 10^{4}, 9.1 \times 10^{2} \pm 37.9,5.2 \times 10^{2} \pm 41.6$ and $5.2 \times 10^{2} \pm 36.1$, respectively. While in the $3^{\text {rd }}$ day were $8 \times 10^{3} \pm 4.9 \times 10^{2}, 5 \times 10^{3} \pm 3.5 \times 10^{2}, 3 \times 10^{3} \pm 57.7$ and $2 \times 10^{3} \pm 2.9 \times 10^{2}$, respectively. On the other hand, in the $6^{\text {th }}$ day the count reach to $1.1 \times 10^{4} \pm 7.6 \times 10^{2}, 7 \times 10^{3} \pm$ $58.4,5 \times 10^{3} \pm 4.6 \times 10^{2}$ and $4 \times 10^{3} \pm 59.3$, respectively. In 
Table 2. Effect of sumac spice extract on $S$. aureus count (CFU/g) in the treated kofta samples

\begin{tabular}{ccccccccc}
\hline \multirow{2}{*}{ Days } & \multicolumn{2}{c}{ Group 1 } & \multicolumn{2}{c}{ Group 2 } & \multicolumn{2}{c}{ Group 3 } & \multicolumn{2}{c}{ Group 4 } \\
\cline { 2 - 8 } & Mean & SE & Mean & SE & Mean & SE & Mean & SE \\
\hline Zero-day & $5.3 \times 10^{3 \mathrm{a}}$ & $5.6 \times 10^{4}$ & $9.1 \times 10^{2 \mathrm{~b}}$ & 37.9 & $5.2 \times 10^{2 \mathrm{~b}}$ & 41.6 & $5.2 \times 10^{2 \mathrm{~b}}$ & 36.1 \\
$3^{\text {rd }}$ day & $8 \times 10^{3 \mathrm{a}}$ & $4.9 \times 10^{2}$ & $5 \times 10^{3 \mathrm{~b}}$ & $3.5 \times 10^{2}$ & $3 \times 10^{3 \mathrm{c}}$ & 57.7 & $2 \times 10^{3 \mathrm{c}}$ & $2.9 \times 10^{2}$ \\
$6^{\text {th }}$ day & $1.1 \times 10^{4 \mathrm{a}}$ & $7.6 \times 10^{2}$ & $7 \times 10^{3 \mathrm{~b}}$ & 58.4 & $5 \times 10^{3 \mathrm{c}}$ & $4.6 \times 10^{2}$ & $4 \times 10^{3 \mathrm{c}}$ & 59.3 \\
$9^{\text {th }}$ day & $\mathrm{S}$ & $\mathrm{S}$ & $7 \times 10^{4 \mathrm{a}}$ & $3.4 \times 10^{3}$ & $9 \times 10^{3 \mathrm{~b}}$ & $1.1 \times 10^{2}$ & $8 \times 10^{3 \mathrm{~b}}$ & $2.9 \times 10^{2}$ \\
$12^{\text {th }}$ day & $\mathrm{S}$ & $\mathrm{S}$ & $1.1 \times 10^{5 \mathrm{a}}$ & $5.7 \times 10^{3}$ & $2.9 \times 10^{4 \mathrm{~b}}$ & $3.1 \times 10^{3}$ & $2 \times 10^{4 \mathrm{~b}}$ & $4.9 \times 10^{3}$ \\
$15^{\text {th }}$ day & $\mathrm{S}$ & $\mathrm{S}$ & $\mathrm{S}$ & $\mathrm{S}$ & $5.5 \times 10^{4 \mathrm{a}}$ & $9.9 \times 10^{2}$ & $3.3 \times 10^{4 \mathrm{a}}$ & $9.7 \times 10^{2}$ \\
\hline
\end{tabular}

Mean values in the same row that are not followed by the same letter are significantly different $(\mathrm{p}<0.05)$. S: spoiled, SE: Standard error

$9^{\text {th }}$ day group 1 spoiled, while group 2, group 3 and group 4; Mean value \pm standard error was $7 \times 10^{4} \pm$ $3.4 \times 10^{3}, \quad 9 \times 10^{3} \pm 1.1 \times 10^{2}$ and $8 \times 10^{3} \pm 2.9 \times 10^{2}$, respectively. In addition, the $12^{\text {th }}$ day Mean value \pm standard errors of treated groups were $1.1 \times 10^{5} \pm$ $5.7 \times 10^{3}, 2.9 \times 10^{4} \pm 3.1 \times 10^{3}$ and $2 \times 10^{4} \pm 4.9 \times 10^{3}$, respectively. Finally, in the $15^{\text {th }}$ day group 2 spoiled, while group 3 and group 4; Mean value \pm standard error was $5.5 \times 10^{4} \pm 9.9 \times 10^{2}$ and $3.3 \times 10^{4} \pm 9.7 \times 10^{2}$, respectively. In the Zero-day, there were a significant difference $(p<0.05)$ between group 1, group 2 while there was not significant difference between group 2, group 3 and group 4 . Meanwhile, in the $3^{\text {rd }}$ day and $6^{\text {th }}$ day there were significant differences between group 1 , group 2 and group 3 while there was not significant difference between group 3 and group 4 . In the $9^{\text {th }}$ and $12^{\text {th }}$ day there were a significant difference $(\mathrm{p}<0.05)$ between group 2 and group 3 while there was no significant difference between group 3 and group 4 . Finally, in the $15^{\text {th }}$ day there were no significant difference $(p>0.05)$ between group 3 and group 4 .

Sumac spice extract significantly $(\mathrm{p}<0.05)$ decreased the total $S$. aureus count of treated samples compared with control samples that spoiled at the $6^{\text {th }}$ day. These obtained results agreed with those reported by Shabir (2012) and Yadolahi et al. (2017).

$S$. aureus count were gradually increased during refrigeration for all treated groups (2, 3 and 4) in different ratios depending on the sumac concentration but still lower than that group 1. According to EOS (2005) group 1 (untreated) were exceeding the permissible limits $10^{2}$ but the treated samples agreed with this limit in the zero-day.
The inhibitory effect of sumac is due to the high citric and malic acid contents (Wetherilt and Pala 1994), which may cause a change in $\mathrm{pH}$ (Sumac $\mathrm{pH}$ value is $2.5)$, this may be a reason for inhibition the bacterial growth.

The results obtained in Table 3 showed the reduction percent of $S$. aureus count (CFU/g) in the treated kofta samples with sumac spice extract at concentrations $1 \%$, $2.5 \%$ and $5 \%$. At concentrations $1 \%$, the reduction percent was $82.8 \%$ in zero-day then decreased to $37.5 \%$ and $36.4 \%$ in the $3^{\text {rd }}$ day and $6^{\text {th }}$ day, respectively while at concentrations $2.5 \%$, the reduction percent was $90.2 \%$, $62.5 \%$ and $54.5 \%$ in the zero-day, $3^{\text {rd }}$ day and $6^{\text {th }}$ day, respectively. At concentrations 5\%, the reduction percent of $S$. aureus count at zero-day, $3^{\text {rd }}$ day and $6^{\text {th }}$ day was $90.2 \%, 75 \%$ and $63.6 \%$ respectively.

These previous results revealed that the highest reduction percent of $S$. aureus count were achieved by sumac spice extract at concentrations 5\% (group 4) followed by concentrations $2.5 \%$ (group 3 ) and the lowest effect was sumac spice extract at concentrations $1 \%$ (group 2).

\subsubsection{Effect of sumac spice extract on} Enterobacteriaceae count

Results in Table 4 showed the effect of sumac spice extract on total Enterobacteriaceae count (CFU/g) in the treated kofta samples. In zero-day, the mean value \pm standard error in group 1 , group 2 , group 3 and group 4 was $2 \times 10^{3} \pm 1.7 \times 10^{2}, 6.3 \times 10^{2} \pm 26.7,2.9 \times 10^{2} \pm 43.3$ and $2.1 \times 10^{2} \pm 15.3$, respectively. While in the $3^{\text {rd }}$ day were $6 \times 10^{3} \pm 2 \times 10^{2}, 5.2 \times 10^{3} \pm 2.2 \times 10^{2}, 2.9 \times 10^{3} \pm 88.2$ and $2.1 \times 10^{3} \pm 2.4 \times 10^{2}$, respectively. On the other hand, in

Table 3. Reduction percentage of $S$. aureus count $(\mathrm{CFU} / \mathrm{g})$ in the treated kofta samples with sumac spice extract at concentrations of $1 \%, 2.5 \%$ and $5 \%$

\begin{tabular}{ccccccccccc}
\hline \multirow{2}{*}{ Day } & Group 1 & \multicolumn{3}{c}{ Group 2 (1\%) } & \multicolumn{3}{c}{ Group 3 (2.5\%) } & \multicolumn{3}{c}{ Group 4 (5\%) } \\
\cline { 2 - 17 } & Mean & Mean & Reduction & $\%$ & Mean & Reduction & $\%$ & Mean & Reduction & $\%$ \\
\hline Zero-day & $5.3 \times 10^{3}$ & $9.1 \times 10^{2}$ & 0.828 & 82.8 & $5.2 \times 10^{2}$ & 0.902 & 90.2 & $5.2 \times 10^{2}$ & 0.902 & 90.2 \\
$3^{\text {rd }}$ day & $8 \times 10^{3}$ & $5 \times 10^{3}$ & 0.375 & 37.5 & $3 \times 10^{3}$ & 0.625 & 62.5 & $2 \times 10^{3}$ & 0.75 & 75 \\
$6^{\text {th }}$ day & $1.1 \times 10^{4}$ & $7 \times 10^{3}$ & 0.364 & 36.4 & $5 \times 10^{3}$ & 0.545 & 54.5 & $4 \times 10^{3}$ & 0.636 & 63.6 \\
\hline
\end{tabular}


Table 4. Effect of sumac spice extract on total Enterobacteriaceae count (CFU/g) in the treated kofta samples

\begin{tabular}{ccccccccc}
\hline \multirow{2}{*}{ Days } & \multicolumn{2}{c}{ Group 1 } & \multicolumn{2}{c}{ Group 2 } & \multicolumn{2}{c}{ Group 3 } & \multicolumn{2}{c}{ Group 4 } \\
\cline { 2 - 8 } & Mean & SE & Mean & SE & Mean & SE & Mean & SE \\
\hline Zero-day & $5.3 \times 10^{3 \mathrm{a}}$ & $5.6 \times 10^{4}$ & $9.1 \times 10^{2 \mathrm{~b}}$ & 37.9 & $5.2 \times 10^{2 \mathrm{~b}}$ & 41.6 & $5.2 \times 10^{2 \mathrm{~b}}$ & 36.1 \\
$3^{\text {rd }}$ day & $8 \times 10^{3 \mathrm{a}}$ & $4.9 \times 10^{2}$ & $5 \times 10^{3 \mathrm{~b}}$ & $3.5 \times 10^{2}$ & $3 \times 10^{3 \mathrm{c}}$ & 57.7 & $2 \times 10^{3 \mathrm{c}}$ & $2.9 \times 10^{2}$ \\
$6^{\text {th }}$ day & $1.1 \times 10^{4 \mathrm{a}}$ & $7.6 \times 10^{2}$ & $7 \times 10^{3 \mathrm{~b}}$ & 58.4 & $5 \times 10^{3 \mathrm{c}}$ & $4.6 \times 10^{2}$ & $4 \times 10^{3 \mathrm{c}}$ & 59.3 \\
$9^{\text {th }}$ day & $\mathrm{S}$ & $\mathrm{S}$ & $7 \times 10^{4 \mathrm{a}}$ & $3.4 \times 10^{3}$ & $9 \times 10^{3 \mathrm{~b}}$ & $1.1 \times 10^{2}$ & $8 \times 10^{3 \mathrm{~b}}$ & $2.9 \times 10^{2}$ \\
$12^{\text {th }}$ day & $\mathrm{S}$ & $\mathrm{S}$ & $1.1 \times 10^{5 \mathrm{a}}$ & $5.7 \times 10^{3}$ & $2.9 \times 10^{4 \mathrm{~b}}$ & $3.1 \times 10^{3}$ & $2 \times 10^{4 \mathrm{~b}}$ & $4.9 \times 10^{3}$ \\
$15^{\text {th }}$ day & $\mathrm{S}$ & $\mathrm{S}$ & $\mathrm{S}$ & $\mathrm{S}$ & $5.5 \times 10^{4 \mathrm{a}}$ & $9.9 \times 10^{2}$ & $3.3 \times 10^{4 \mathrm{a}}$ & $9.7 \times 10^{2}$ \\
\hline
\end{tabular}

Mean values in the same row that are not followed by the same letter are significantly different $(p<0.05)$. S: spoiled, SE: Standard error

the $6^{\text {th }}$ day the count reach to $1 \times 10^{4} \pm 3.5 \times 10^{2}, 9.1 \times 10^{3} \pm$ $1.7 \times 10^{2}, \quad 8 \times 10^{3} \pm 5.7 \times 10^{2}$ and $7.1 \times 10^{3} \pm 1.7 \times 10^{2}$, respectively. In $9^{\text {th }}$ day group 1 spoiled, while group 2 , group 3 and group 4; Mean value \pm standard error was $1.1 \times 10^{4} \pm 1 \times 10^{3}, 9 \times 10^{3} \pm 1.7 \times 10^{2}$ and $8.1 \times 10^{3} \pm 77.7$, respectively. In addition, the $12^{\text {th }}$ day Mean value \pm standard errors of treated groups were $3.9 \times 10^{4} \pm$ $1.4 \times 10^{3}, \quad 1.1 \times 10^{4} \pm 7 \times 10^{2}$ and $9.1 \times 10^{3} \pm 1.7 \times 10^{2}$, respectively. Finally, in the $15^{\text {th }}$ day group 2 spoiled, while group 3 and group 4; Mean value \pm standard error was $4 \times 10^{4} \pm 1.4 \times 10^{3}$ and $5 \times 10^{4} \pm 1.4 \times 10^{3}$, respectively. In the Zero, there were a significant difference $(p<0.05)$ between group 1, group 2 and group3, while there was no significant difference between group 3 and group 4 . Meanwhile, in the $3^{\text {rd }}$ day there were significant differences between all groups. In the $6^{\text {th }}$ day there were a significant difference $(\mathrm{p}<0.05)$ between group 1 , group 2 and group 4, while concerning to group 3 no significant appeared. In the $9^{\text {th }}$ day there were significant differences $(p<0.05)$ between group 2 and group 4 , while concerning to group 3 no significant appeared. In the $12^{\text {th }}$ day there were a significant difference $(\mathrm{p}<0.05)$ between group 2 and group 3 while there were no significant differences between group 3 and group 4. Finally, in the $15^{\text {th }}$ day there were no significant differences $(p>0.05)$ between group 3 and group 4 .

Total Enterobacteriaceae count significantly $(\mathrm{p}<0.05)$ decreased in treated samples with sumac extract compared with untreated one that spoiled at the $6^{\text {th }}$ day, so generally sumac with different concentrations can effectively act against Enterobacteriaceae. The obtained results agreed with those reported by Vatansever et al. (2008) and Langroodi et al. (2018).

It could be observed that group 1 (control) had the highest Enterobacteriaceae count at any time of refrigeration compared to other treated groups that count gradually increased during refrigeration for all treated groups (2, 3 and 4$)$ but still lower than that group 1.

This results may be due to sumac contains phenolic compounds and tannic acids that have anti-bacterial effect (Langroodi et al. 2018).

The results in Table 5 showed the reduction percent of Enterobacteriaceae count (CFU/g) in the treated kofta samples with sumac spice extract at concentrations $1 \%$, $2.5 \%$ and $5 \%$. At concentration $1 \%$, the reduction percent was $68.7 \%$ in zero-day then decreased to 14.35 $\%$ and reach to $12 \%$ in the $3^{\text {rd }}$ day and $6^{\text {th }}$ day, respectively while at concentration $2.5 \%$, the reduction percent was $85.2 \%$, which is the highest percentage, followed by $50.8 \%$ then $22.3 \%$ in the zero-day, $3^{\text {rd }}$ day and $6^{\text {th }}$ day respectively. At concentrations $5 \%$, the reduction percent of Enterobacteriaceae count $(\mathrm{CFU} / \mathrm{g})$ in the treated samples at zero-day, $3^{\text {rd }}$ day and $6^{\text {th }}$ day was $89.5 \%, 64.6 \%$ and $31.4 \%$ respectively.

It's appeared from previous results that the highest reduction percent of Enterobacteriaceae count were achieved by sumac spice extract at concentrations 5\% (group4) followed by concentrations $2.5 \%$ (group 3) and the lowest effect was sumac spice extract at concentrations $1 \%$ (group 2).

\section{Conclusion}

Incidence of food poisoning bacteria in kofta constitute a public health hazard and considered as indicator of poor production, post processing contamination or fecal contamination where the most

Table 5. Reduction percentage of Enterobacteriaceae count (CFU/g) in the treated kofta samples with sumac spice extract at concentrations of $1 \%, 2.5 \%$ and $5 \%$

\begin{tabular}{|c|c|c|c|c|c|c|c|c|c|c|}
\hline \multirow{2}{*}{ Day } & \multirow{2}{*}{$\begin{array}{c}\text { Group } 1 \\
\text { Mean }\end{array}$} & \multicolumn{3}{|c|}{ Group $2(1 \%)$} & \multicolumn{3}{|c|}{ Group $3(2.5 \%)$} & \multicolumn{3}{|c|}{ Group $4(5 \%)$} \\
\hline & & Mean & Reduction & $\%$ & Mean & Reduction & $\%$ & Mean & Reduction & $\%$ \\
\hline Zero-day & $2 \times 10^{3}$ & $6.3 \times 10^{2}$ & 0.8670 & 68.7 & $2.9 \times 10^{2}$ & 0.852 & 85.2 & $2.1 \times 10^{2}$ & 0.895 & 89.5 \\
\hline $3^{\text {rd }}$ day & $6 \times 10^{3}$ & $5.2 \times 103$ & 0.1435 & 14.35 & $2.9 \times 10^{3}$ & 0.508 & 50.8 & $2.1 \times 10^{3}$ & 0.646 & 64.6 \\
\hline $6^{\text {th }}$ day & $1 \times 10^{4}$ & $9.1 \times 10^{3}$ & 0.12 & 12 & $8 \times 10^{3}$ & 0.223 & 22.3 & $7.1 \times 10^{3}$ & 0.314 & 31.4 \\
\hline
\end{tabular}


important food poisoning pathogens associated with products are $S$. aureus and Enterobacteriaceae. The availability of many herbs and spices nowadays makes the use of their extracts an effective alternative to synthetic preservative which poses a public health hazard. Sumac spice extract can be used in kofta by different concentrations during processing to increase the shelf life and reduced the microbial load of S.aureus and Enterobacteriaceae in examined kofta samples during storage.

\section{Conflict of interest}

The authors declare no conflict of interest.

\section{References}

Abd El-Mawla, A.M.A. (1996). A pharmacognostical study of Astragalussie beri DC Family Leguminosae growing in Egypt. Egypt: Assiut University, MSc. Thesis.

Abou-Reidah, I. Jamous, R. and Shtayeh, M. (2014). Phytochemistry, pharmacological properties and industrial applications of Rhus coriaria L. Jordan Journal of Biological Sciences, 7(4), 233-244. https://doi.org/10.12816/0008245

Abu-Shanab, B., Adwan, G., Abu-Safiya, D., Adwan, K. and Abu-Shanab, M. (2005). Antibacterialactivity of Rhus coriaria L. extracts growing in Palestine. Journal of Islamic University of Gaza, 13(2), 147153.

Akrayi, H.F.S. and Abdullrahman, Z.F.A. (2013). Screening in vitro and in vivo the antibacterial activity of Rhus coriaria extract against Staphylococcus aureus. International Journal of Recent Research and Applied Studies, 15(3), 390397.

Ali, S.M.S., Al-Assali, A.A. and Jamous, R.M. (2013). Antimicrobial Activity of Palestinian Medicinal Plants against Acne-inducing Bacteria. African Journal of Microbiology Research, 7(21), 25602573. https://doi.org/10.5897/AJMR12.1875

Aliakbarlu, J., Mohammadi, S.and Khalili, S. (2014). A Study on Antioxidant Potency and Antibacterial Activity of Water Extracts of Some Spices Widely Consumed in Iranian Diet. Journal of Food Biochemistry, 38(2), 159-166. https:// doi.org/10.1111/jfbc.12034

Al-Mizraqch, A.S., Al-Dhaher, Z.A. and Mahmood, M.A. (2010). Antimicrobial activity of aqueous extracts of pomegranate, sumac, sage, anise, hand bull tongue, thyme, cloves, lemon and mint against some foodborne pathogens. Iraqi Journal of Veterinary Medicine, 34(2), 85-94.
Bonjar, S. (2004). Evaluation of antibacterial properties of some medicinal plants used in Iran. Journal of Ethnopharmacology, 94(2-3), 301-305. https:// doi.org/10.1016/j.jep.2004.06.007

Burt, S. (2004), Essential oils: their antibacterial properties and potential applications in foods-a review. International Journal of Food Microbiology, 94(3), 223-253. https:// doi.org/10.1016/j.ijfoodmicro.2004.03.022

Cowan, M.M. (1999). Plant products as antimicrobial agents. Clinical Microbiology Reviews, 12(4), 564582. https://doi.org/10.1128/CMR.12.4.564

Downer, F.P. and Ito, K. (Eds.) (2001). Compendium of methods for microbiological examination of food. $4^{\text {th }}$ ed. Washington DC, USA: American Public Health Association.

EOS. (Egyptian Organization for Standarization and Quality). (2005). Frozen Balls. 1973/2005. Egypt.

Ertürk, Ö. (2010). Antibacterial and antifungal effects of alcoholic extracts of 41 medicinal plants growing in Turkey. Czech Journal of Food Sciences, 28(1), 5360. https://doi.org/10.17221/144/2008-CJFS

European Medicines Agency (2013). Propylene glycol used as an excipient. Retrieved from website : https://www.ema.europa.eu/en/documents/report/ propylene-glycol used excipient-report-publishedsupport-questions-answers-propylene-glycol used_en.pdf

Fazeli, M.R., Amin, G., Attari, M.M.A., Ashtiani, H., Jamalifar, H. and Samadi, N. (2007). Antimicrobial activities of Iranian sumac and avishan-e shirazi (Zataria multiflora) against some food-borne bacteria. Food Control Journal, 18(6), 646-649. https://doi.org/10.1016/j.foodcont.2006.03.002

Gabr, S.A., El-Metwally, M.M. and Al-Ghadir, A.H. (2014). Antioxidant and antibacterial active constituents of Rhuscoriaria. Biotechnology, 13(2), 37-45. https://doi.org/10.3923/biotech.2014.37.45

Hassan, M.A., Amin, R.A. and El-Salhy, M.S. (2015), Bacteriological and Chemical Evaluation of Meat Meals in Some Egyptian Hotels. Benha Veterinary Medical Journal, 29(2), 80-91. https:// doi.org/10.21608/bvmj.2015.31553

ISO (International Organization for Standardization). (2004). Microbiology of food and animal feeding stuffs. Horizontal methods for the detection and enumeration of Enterobacteriaceae. Part 2: colonycount method. ISO 21528-2:2004. Geneva, Switzerland: ISO.

Khalkhali, F. and Noveir, M. (2018). Effect of Sumacc (Rhuscoriaria) and rosemary (Rosmarinus officinalis) water extracts on microbial growth changes in ground beef meat. Journal of Food and 
Bioprocess Engineering, 2(2), 33-40.

Langroodi, A.M., Tajik, H. and Mehdizadeh, T. (2018).

Preservative effects of sumac hydro-alcoholic extract and chitosan coating enriched along with Zataria multiflora Boiss essential oil on the quality of beef during storage. Veterinary Research Forum, 9(2), 153-161. https://doi.org/10.30466/VRF.2018.30831

Mahdi, M.A.A., Amini, M., Farsam, H., Amin, G., Fazeli, M.R., Esfahani, H.R.M., Jamalifar, H. and Bairami, A. (2016). Isolation of major active antibacterial compounds of Sumac fruit (Rhus coriaria L.). International Journal of Enteric Pathogens, 4(4), 1-5. https://doi.org/10.15171/ ijep.2016.11

McEvovy, J.M., Sheridan, J.J., Blair, I.S. and McDowell, D.A. (2004). Microbial contamination on beef in relation to hygiene assessment based on criteria used in EU Decision 2001/ 471/ E.C. International Journal of Food Microbiology, 92, 217 - 225. https:// doi.org/10.1016/j.ijfoodmicro.2003.09.010

Moshtaghi, H., Abbasvali, M., Mohammadi, E., Safian, A.R. and Adel, M.(2013). Investigation of antimicrobial effects of ethanolic extract of sumac (Rhus coriaria L.) against Escherichia coli in vitro. Journal of Food Hygiene, 2(10), 1-8.

Nalawade, T.M., Bhat, K. and Sogi, S.H. (2015). Bactericidal activity of propylene glycol, glycerine, polyethylene glycol 400, and polyethylene glycol 1000 against selected microorganisms. Journal of International Society of Preventive and Community Dentistry, 5(2), 114-119. https:// doi.org/10.4103/2231-0762.155736

Nasar, A.S., Halkman, A.K. and Al-Haq, M.I. (2004). Inhibition of some foodborne bacteria by alcohol extract of sumac (Rhus coriaria L.). Journal of Food Safety, 24(4), 257-267. https://doi.org/10.1111/ j.1745-4565.2004.00506.x

National Committee for Clinical Laboratory Standards. (1993). Performance standards for antimicrobial disk susceptibility tests. Approved standard. NCCLS document M2-A5. Wayne, Pa, USA: National Committee for Clinical Laboratory Standards.

Nimri, L.F., Meqdam, M.M. and Alkofahi, A. (1999). Antibacterial activity of Jordanian medicinal plants. Pharmaceutical Biology, 37(3), 196-201. https://doi.org/10.1076/phbi.37.3.196.6308

Qadir, F.A., Sabr, Z.N. and Sabr, D.R. (2013). Effects of pomegranate, sumac, and Aloe vera extracts on Escherichia coli, Staphylococcus aureus, and Citrobacter isolated from urinary tract infection. Egypt Journal of Experimental Biology, 9 (1), 41-48.
Raodah, M., Al-Ali, A.Z.H. and Faleeha, H.H. (2014). The Antioxidant and Antimicrobial of Syrian Sumac (Rhus coriaria) Fruit Extracts. Journal of Natural Sciences Research, 4(11), 36-40.

Ravindran, P.N., Pillai, G.S. and Divakaran, M. (2012). Other herbs and spices: mango ginger to wasabi. In Peter, K.V. (Ed.). Handbook of herbs and spices. Vol. 2, p. 557-582. USA: Woodhead Publishing. https://doi.org/10.1533/9780857095688.557

Saad, M.S., Dalia, F.K. and Sara, M.Z. (2018). Food Poisoning Bacteria in Ready to Eat Meat and Chicken Meat Products. Benha Veterinary Medical Journal, 35(1), 301-310. https://doi.org/10.21608/ bvmj.2018.38771

Saxena, G., McCutcheon, A., Farmer, S., Towers, G. and Hancock, R. (1994). Antimicrobial constituents of Rhus glabra. Journal of Ethnopharmacology, 42(2), 95-99. https://doi.org/10.1016/0378-8741(94)901023

Shabir, A. (2012). Rhus coriaria linn, a plant of medicinal, nutritional and industrial Importance: a review. Journal of Animal and Plant Sciences, 2(2), 505-512.

SPSS. (2007). Statistical Package for Social Science Version 16 for Windows. Chicago: SPSS

Srinivasan, K. (2005). Role of spices beyond food flavoring: Nutraceuticals with multiple health effects. Food Reviews International, 21(2), 167-188. https://doi.org/10.1081/FRI-200051872

United States Department of Agriculture, Food Safety and Inspection Service (FSIS). (2003). Beef from farm to table. Retrieved from FSIS, USDA website: https://www.fsis.usda.gov/wps/portal/fsis/topics/food -safety-education/get-answers/food-safety-factsheets/meat-preparation/beef-from-farm-to-table/ ct_index

Vatansever, L., Gülmez, M., Nebahat, O.R.A.L., Güven, A. and Salih, O.T.L.U. (2008). Effects of sumac (Rhus coriaria L), oregano (Oreganum vulgare L.) and lactic acid on microbiological decontamination and shelf-life of raw broiler drumsticks. Kafkas Üniversitesi Veteriner Fakültesi Dergisi, 14(2), 211216.

Wetherilt, H. and Pala, M. (1994).Herbs and spices indigenous to Turkey. In Charalambous, G. (Ed.) Spices, herbs and edible fungi. $1^{\text {st }}$ ed., p. 285-307. USA: Elsevier.

Yadolahi, B.M., Pajohi, A.M. and Bazargani, G.B. (2017). Behavior of Staphylococcus aureus affected by sumac water extract in vitro and Koobideh Kebab. Journal of Food Processing and Preservation, 41(4), e13078. https://doi.org/10.1111/ jfpp.13078 